\title{
Peran Budaya Organisasi Birokrasi dalam Meningkatkan Kinerja Pelayanan Publik
}

\author{
Budi Setiawati ${ }^{\text {a }}$ \\ ${ }^{a}$ STIA Tabalong, Kalimantan Selatan, Indonesia
}

\section{INFORMASI ARTIKEL}

\section{Article history:}

Dikirim tanggal: 20 September 2016

Revisi pertama tanggal: 30 September 2016

Diterima tanggal: 11 November 2016

Tersedia online tanggal: 28 November 2016

Keywords: organisation bureaucracy culture, performance, public services

\section{ABSTRACT}

This article aims to analyze the paradigm shift in the government bureaucracy organization's culture of innovation. In fact, innovation has given a change space and also has a real value in the culture of government organization. This can be proved by the countries in the Asian region continuously make the country become more advanced in their environment. This concept would affect bureaucratic reform in the context of Indonesia. Innovation in the cultural role of bureaucratic organization aims to improve the performance in public services optimally by not changing its identity as professional waiters, which also means changing the mindset of the bureaucratic apparatus more open and adapt to change circumstances within the bureaucracy and as a result of the higher development of science and technology science.

\section{INTISARI}

Tulisan artikel ini adalah bertujuan untuk menganalis pergeseran paradigma pada budaya inovasi organisasi birokrasi pemerintahan. Inovasi telah memberikan ruang perubahan serta memiliki nilai yang sesungguhnya dalam budaya organisasi pemerintahan. Hal ini dapat dibuktikan oleh negara-negara di kawasan Asia secara terus menerus menjadikan negara dilingkungannya menjadi semakin maju. Konsep ini akan mempengaruhi reformasi birokrasi dalam konteks Indonesia. Inovasi dalam peran budaya organisasi birokrasi bertujuan untuk meningkatkan kinerja pelayanan publik secara optimal dengan tidak merubah jati dirinya sebagai pelayan yang professional, yang berarti juga harus merubah pola berpikir para aparatur birokrasi secara lebih terbuka dan dapat beradaptasi dengan perubahan situasi dan kondisi dalam birokrasi tersebut maupun perubahan akibat dari perkembangan ilmu pengetahuan dan ilmu teknologi yang semakin tinggi.

\section{Pendahuluan}

Budaya organisasi berkaitan dengan bagaimana karyawan memahami karakteristik budaya suatu organisasi, dan tidak terkait dengan apakah karyawan menyukai karakteristik itu atau tidak, oleh sebab itu budaya organisasi adalah suatu sikap deskriptif yang berupaya mengukur bagaimana karyawan memandang organisasi mereka, apakah mendorong kerja tim? apakah menghargai inovasi? apakah menekan inisiatif?

Budaya organisasi tersebut memberikan ruang penjelasan bagi budaya organisasi birokrasi pemerintahan. Fakta dan fenomena dilapangan menunjukan kinerja aparatur birokrasi selama ini terkesan berbelit-belit, kurang mendapat kepercayaan masyarakat. Jaminan adanya Undang-Undang Pelayanan 
Publik nampaknya belum cukup, implementasi UndangUndang Nmor 25 Tahun 2009 tentang Pelayanan Publik menjadi lebih penting, dimana banyak masyarakat masih belum mendapatkan pelayanan publik dan masih belum sesuai dengan harapannya. Masyarakat mengakui adanya peningkatan pelayanan publik, namun peningkatan tersebut belum sesuai dengan harapannya.

\section{Pembahasan}

Timbulnya kesan negatif dan hilangnya kepercayaan publik terhadap pemerintah disebabkan karena selama ini kinerja aparatur birokrasi dalam memberikan pelayanan tidak dapat merespon kebutuhan masyarakat. Hal ini dapat dibuktikan seringnya aparatur birokrasi yang suka menunda-nunda pekerjaannya. Oleh sebab itu perlu perbaikan kinerja aparatur birokrasi dalam memberikan pelayanan yang optimal melalui budaya organisasi yang tidak dapat dihindari. Hal ini sebagaimana yang diungkapkan oleh Mauk dalam Budi Setiono (2002:109) yang menyatakan:

We need to change the culture of public administrator organizations;... slowness turn to quickness, top-down approaches to a bottom up philosophy, bureaucracy turn to neighborhoods, bigness to smallness.

Birokrasi yang selama ini didesain untuk bekerja lambat, berhati-hati dan metodologinya sudah tidak diterima oleh orang yang perlu layanan cepat, efisien, tepat waktu dan sederhana. Dalam era globalisasi yang penuh kompetisi, gerak cepat dan tindakan aparat pemerintah yang tepat merupakan suatu keharusan. Untuk meningkatkan daya saing yang kian kompetitif diperlukan reformasi birokrasi yang dapat menghasilkan birokrasi profesional dan ramping yang bebas hambatan. Hal ini membutuhkan dilaksanakannya penyelenggaraan pemerintahan yang baik (good local governance), dengan menerapkan prinsip akuntabilitas, transparansi, dan keterbukaan, efisiensi dan efektifitas, serta partisipasi, penegakan hukum, keadilan, orientasi konsensus, pemimpin memiliki visi yang luas, cepat dan tanggap melayani kepentingan public, yang pelaksanaannya dilaksanakan secara demokratis sebagai suatu kesatuan yang utuh (Rondinelli dalam Mulyadi dkk, 2016).

Untuk dapat meningkatkan kinerja aparatur dalam memberikan pelayanan yang optimal, yaitu melalui peran budaya organisasi birokrasi sekaligus merupakan bagian dari reformasi birokrasi. Salah satu unsur budaya organisasi birokrasi adalah berkembangnya inovasi dalam instansi pemerintah. Sebab inovasi merupakan hal sangat strategis yang memungkinkan birokrasi untuk berfungsi lebih dinamis dan melakukan improvement. Sehingga kinerja pelayanan publik dapat lebih baik. Hal ini dapat dibuktikan dari beberapa hasil penelitian menunjukan bahwa budaya organisasi sangat berpengaruh terhadap kinerja karyawan atau pegawai.

Kurang populernya konsep inovasi pada masa lalu dapat dipahami karena pegawai kurang memahami karakteristik budaya organisasi itu sendiri dan makna reformasi yang lebih didasarkan pada prinsip-prinsip birokrasi Weber. Dalam konsepsi Weber, birokrasi memerlukan aturan yang jelas, hirarki, spesialisasi dan lingkungan yang relatif stabil, sehingga aparatur cenderung tidak memiliki inovasi dan inisiatif. Dalam konteks ini, inovasi dipandang tidak banyak diperlukan bagi aparatur birokrasi pemerintah (Kelman yang dikuti oleh Asropi, 2008). Kewajiban aparatur birokrasi pemerintah adalah menjalankan aturan yang telah ditetapkan (rule driven). Kalaupun inovasi dilakukan, tetapi hanya terbatas pada kalangan pimpinan saja dan hanya dilakukan pada hal-hal yang relatif kecil.

Oleh sebab itu instansi pemerintah dan departemen sekarang berlomba-lomba memperbaiki diri dalam pelayaan publik. Untuk itu beberapa instansi dipemerintahan daerah siap berkontribusi membangun inovasi pelayanan publik yang masih konvensional. Kompetisi Inovasi Pelayanan Publik Tahun 2016 dijadikan momentum untuk melakukan perubahan dan membangun pelayanan yang cepat, tepat dan bertanggung jawab. Berbagai upaya pemerintah untuk mendorong inovasi pada birokrasi melalui berbagai penghargaan, juga tidak banyak menunjukan hasil sebagaimana yang diharapkan. Inovasi belum menjadi unsur penting dari budaya birokrasi pemerintah. Hal demikian ini juga mengindikasikan bahwa birokrasi pemerintah sekarang belum mampu menyerap dan mengembangkan nilai-nilai manajemen yang lebih maju.

Oleh sebab itu kinerja pelayanan publik yang diberikan oleh birokrasi pemerintah dilakukan lebih efisien dan berkualitas dengan tidak mengurangi dan mengubah mindset bahwa birokrasi menjadi lebih penting dalam upaya peningkatan pelayanan kepada masyarakat. Dengan demikian diharapkan dapat menghilangkan image, bahwa pelayanan publik yang diberikan birokrasi pada masyarakat lambat dan berbelit-belit.

Hadirnya konsep Paradigma New Public Management (NPM) mengalami pergeseran dalam reformasi administrasi (Osborne, David and Peter Plastrik, 1997). Konsep NPM tidak hanya melihat sebagai perubahan teknologi saja, namun lebih kepada orientasi ekonomi, hubungan sosial dengan masyarakat (Muhammad, 2008). Reformasi kemudian diadopsi oleh pemerintahan yang dikemukakan oleh David Osborn (1992) menyatakan bahwa birokrasi harus mengedepankan hasil, partisipasi, berorientasi pada pelanggan, dan digerakan oleh misi,serta desentralisasi. Zaman reformasi dewasa ini, peran inovasi justru sangat 
dihargai oleh pendukung gerakan reformasi. Negara Korea, konsep inovasi ini bahkan telah "menggantikan" konsep reformasi. Secara empiris di Korea ini menunjukkan bahwa penerapan inovasi pada negara tersebut sudah dapat meningkatkan kualitas penyelenggaraan pemerintahan ditingkat lokal (Yoo, dalam Asropi, 2008). Keberhasilan sebagaimana di Korea ini juga terjadi pada penerapan inovasi di Kanada (Robertson and Balldalam Asropi 2008). Sementara di Cina, inovasi telah dianggap sebagai bagian dari tradisi Cina (Shenkar dalam Asropi 2008). Inovasi atas birokrasi sangat mendukung bagi berkembangnya ekonomi dan ilmu teknologi di Negara Cina dewasa ini. Oleh sebab itu inovasi merupakan sebuah nilai yang sangat berharga untuk setiap perubahan yang dinginkan.

Oleh sebab itu, budaya inovasi pada birokrasi harus dapat membangun tumbuhnya budaya keterbukaan (demokrasi). Sehingga akan mengembalikan tingkat kepercayaan masyarakat kepada pemerintah lokal (daerah), dan akan berdampak pada percepatan peningkatan kesejahteraan masyarakatsecara luas.

Salah satu budaya yang sangat penting bagi keberhasilan reformasi birokrasi adalah budaya inovasi. Di Indonesia budaya organisasi birokrasi pemerintah, belum merupakan suatu nilai yang utama dari budaya birokrasi. Padahal birokrasi yang inovatif merupakan salah satu faktor yang sangat penting untuk membangun pemerintahan kedepannya menjadi pemerintahan yang bersih, dan berwibawa serta bertanggungjawab. Agar pemerintahan ini dapat mempertahankan inovasinya adalah dengan cara selalu mau beradaptasi dalam perubahan baik dari aspek ilmu pengetahuan maupun dari ilmu teknologi. Sebab kunci sukses dari inovasi adalah perubahan yang stabil (konstan).

Kemampuan inovasi akan melahirkan kreatifitas dan menjadikan inovasi yang efektif. Sebab bagi birokrasi pemerintah kemampuan berinovasi dari masing-masing lembaga pemerintahlah yang sesungguhnya sangat berperan didalam menciptakan kreatifitas dan inovasi yang berakhir pada meningkatnya kinerja birokrasi pemerintah. Kemampuan berinovasi dalam birokrasi akan dimaknai sebagai kemampuan birokrasi pemerintah dalam pengembangan penggunaan atau mobilisasi pengetahuan, keterampilan (termasuk keterampilan teknologi) dan pengalaman untuk menciptakan atau memperbaiki produk layanan, proses, dan atau sistem yang baru, yang memberikan nilai yang berarti atau secara signifikan (terutama ekonomi dan sosial). Oleh sebab itu budaya inovasi yang dilakukan oleh pemerintah tidaklah berdiri sendiri tetapi saling berkaitan dengan berbagai aspek managemen strategik, kualitas sumberdaya manusia dan sumber daya material.
Budaya inovasi birokrasi dari masing-masing lembaga pemerintah melakukan budaya inovasi yang berbeda-beda, sebab setiap lembaga pemerintah ingin menonjolkan karakteristik budayanya masing-masing sehingga lembaga tersebut memiliki icon atau ciri dari lembaganya. Hal ini terdapat beberapa faktor yang menjadi penyebabnya, baik faktor internal maupun faktor eksternal dari lembaga. Oleh sebab itu beberapa faktor tersebut sangatlah penting untuk menemukenali, terutama untuk membangun strategi kebijakan yang memadai bagi peningkatan kemampuan inovasi suatu lembaga pemerintah. Persoalannya adalah, untuk menemukenali terhadap faktor-faktor tersebut, bukanlah pekerjaan yang mudah. Bahkan, pada lembaga-lembaga yang telah berhasil melakukan inovasi sekalipun dan hanya sedikit saja yang memahami faktorfaktor yang membuat suksesnya inovasi.

Berbagai permasalahan dalam birokrasi pemerintah yang selama ini telah menjadi isu publik adalah merupakan indikasi dari lemahnya kinerja reformasi birokrasi. Hal ini karena budaya organisasi birokrasi yang diterapkan selama ini untuk mereformasi birokrasi tampaknya belum banyak menyentuh aspek penting dalam budaya birokrasi pemerintah, sehingga kinerja pelayanan publik menjadi terhambat. Sebab hal ini menyangkut keyakinan, sistem nilai-nilai, normanorma dan sikap prilaku yang dimiliki oleh aparatur birokrasi yang nantinya akan menunujang kinerja pelayanan publik. Oleh sebab itu budaya inovasi birokrasi membutuhkan inovator-inovator yang handal.

Inovasi membutuhkan kreativitas, setiap aparat birokrasi tentunya selalu berpikir kreatif inovatif dan dapat menterjemahkan kedalam bentuk tindakan yang diinginkan dan bernilai jual tinggi dalam rangka meningkatkan kinerja pelayanan publik.

Paling tidak ada 20 poin penting dalam menggagas orang yang inovator (Mitchell Ditkoff) yang dikutip oleh Akhmad Sudrajat (2008), yaitu sebagai berikut:

a) Tidak merasa cepat puas dengan keadaan yang ada dan selalu mempertanyakan otoritas dan rutinitas;

b) Senantiasa mengeksplorasi lingkungannya dan menginvestigasi kemungkinan-kemungkinan baru dan memiliki rasa kekaguman (sense of awe);

c) Tanggap terhadap kebutuhan dari dalam (inner needs) senantiasa secara proaktif memprakarsai proyek-proyek baru, menghargai setiap usaha;

d) Visioner; memiliki imaginasi yang tinggi dan memiliki pandangan yang jauh kedepan;

e) Memunculkan ide-ide "gila", memandang sesuatu yang tidak mungkin menjadi sebuah kemungkinan, memimpikan dan menghayalkan sesuatu yang besarbesar;

f) Melampaui wilayah yang dianggap menyenangkan, berani mencoba dan menanggung kegagalan; 
g) Merubah lingkungan kerja sesuai dengan yang dibutuhkan, senang melakukan pekerjaan untuk memperoleh inspirasi atau pemikiran yang segar;

h) Memiliki ketertarikan terhadap hal-hal yang aneh dan mengagumkan, berani tampil beda, bertindak nekad, serta mudah dan sering tertawa layaknya seorang anak kecil;

i) Dapat mempertahankan ide-idenya dan menganggap "kesempurnaan sebagai musuh kebaikan", tidak terikat dengan apa-apa yang dipandang baik menurut orang lain;

j) Terbuka bagi setiap perubahan, mampu melakukan penyesuain terhadap rencana-rencana bagi setiap perubahan, menyajikan berbagai solusi dan gagasan;

k) Mampu melihat hubungan-hubungan dianatara unsur-unsur yang terputus, mensintesakan dan mengkombinasikannya;

1) Menginkubasi setiap masalah dan tantangan, mencari dan merenungkan berbagai pertimbangan dalam mengambil keputusan; dan

m) Perseptif terhadap sesuatu dan dapat membedakannnya, dapat melihat kecenderungan dan prinsip serta mampu mengorganisasikannya, dapat melihat "the Big Picture".

Sebenarnya, pemerintahan kita sudah mengalami suatu kemajuan yang cukup berarti dalam melakukan perubahan seperti kebijakan e-government, kontrak pelayanan, desentralisasi dan otonomi daerah. Namun diharapkan pemerintah berusaha untuk menerapkan budaya inovasi yang merupakan salah satu budaya organisasi birokrasi pemerintah agar dapat meningkatkan kinerja pelayanan publik secara optimal baik ditingkat pusat maupun ditingkat daerah.

\section{Kesimpulan}

Organisasi birokrasi pemerintahan yang memiliki budaya organisasi yang baik, cenderung memiliki kinerja pelayanan publik yang lebih baik pula. Budaya inovasi birokrasi salah satu budaya organisasi yang sangat menentukan keberhasilan dan kesuksesan sebuah pemerintah yang akuntabel dan efisien. Untuk itu budaya inovasi dalam birokrasi dapat dilakukan yang dimulai dengan mengubah pola pikir dan sikap prilaku aparat birokrasi yang didukung oleh kualitas sumberdaya manusia untuk mendukung pengembangan ilmu pengetahuan dan teknologi dalam menghadapi persaingan di era globalisasi sekarang ini. Penerapan budaya inovasi birokrasi secara terus menerus oleh pemerintah pusat maupun pemerintah daerah dapat merespon tuntutan kebutuhan masyarakat. Oleh sebab itu hubungan antara birokrasi dengan pelaku bisnis dan masyarakat di jalin dengan transparan dan akuntabilitas yang tinggi sehingga terwujudnya pemerintahan yang bersih dan berwibawa. Dan semakin meningkatnya kinerja pelayanan publik.

\section{Daftar Pustaka}

Asropi. (2008). Budaya Inovasi dan Reformasi Birokrasi. Jurnal Ilmu Administrasi, Volume V, Nomor 3, September, pp.246-255.

Deddy, Mulyadi dkk. (2016). Administrasi Publik Untuk Pelayanan Publik (Konsep dan Praktek Administrasi dalam Penyusunan SOP: Standar Pelayanan, Etika Pelayanan, Inovasi untuk Kinerja Organisasi). Penerbit Alfabeta, Bandung.

Muhammad, Fadel. (2008). Reinventing Local Government: Pengalaman Dari Daerah, Editor: Rayendra L.Toruan. PT Elex Media Komputindo Kompas Gramedia, Jakarta.

Osborn, David., \& Gaebler, Ted. (1992). Reinventing Government: How the Entepreuneurial Spirit is Transforming the Public Sector. Hodson-Wesley Publishing Company, Inc, New York.

Osborne, David., \& Plastrik, Peter. (1997). Banishing Bureaucracy: The Five Strategies for Reinventing Government. Hodson-Wesley Publishing Company Inc, New York.

Setiono, Budi. (2002). Jaring Birokrasi: Tinjauan dari Aspek Politik dan Administrasi. Bekasi: Gugus Press.

Sudrajat, Akmad. (2008). 20 Ciri-ciri Orang yang Inovatif. Dapat diakses pada https://akhmadsudrajat.wordpress.com/2008/03/1 5/inovatif/comment-page-4/ [Diakses 01 September 2016]. 